\title{
Advancing clinical genetics diagnostic skills: Cherubism
}

\author{
Aamir Jalal Al Mosawi \\ ${ }^{1}$ Advisor in Pediatrics and Pediatric Psychiatry, Children Teaching Hospital of Baghdad Medical City. \\ ${ }^{2}$ Head, Iraq Headquarter of Copernicus Scientists International Panel, Baghdad, Iraq. \\ *Corresponding Author: Aamir Jalal Al Mosawi, 1Advisor in Pediatrics and Pediatric Psychiatry, Children Teaching Hospital of Baghdad \\ Medical City, Head, Iraq Headquarter of Copernicus Scientists International Panel, Baghdad, Iraq. \\ Received date: February 08, 2021; Accepted date: February 19, 2021; Published date: February 26,2021 \\ Citation: Aamir Jalal Al Mosawi. (2021) Advancing clinical genetics diagnostic skills: Cherubism. Journal of Clinical and Laboratory Research. \\ 2(2) DOI: $10.31579 / 2768-0487 / 009$ \\ Copyright: ()2021 Aamir Jalal Al Mosawi. This is an open-access article distributed under the terms of the Creative Commons Attribution \\ License, which permits unrestricted use, distribution, and reproduction in any medium, provided the original author and source are credited.
}

\section{Abstract}

Background: Cherubism is a very rare, mostly a childhood condition that can be horribly disfiguring. We have previously reported our extensive experiences with the diagnosis of rare genetic disorders in a plethora of publications. We have previously reported a large number of rare conditions in Iraq, and we have also helped physicians in the diagnosis and publication of rare syndromes observed in other countries. The aim of this papers is to help physicians in advancing the diagnostic skills in the field of clinical genetics by reviewing briefly a rare syndrome that have not been reported in Iraq, but it is associated with certain clinical characteristics that allow an early diagnosis when seen for the first time.

Patients and methods: During the last week of January, 2021, several TV channels presented and discussed the problem of two brothers from Egypt who were considered to have a very rare poorly defined condition that has been associated with progressive disfigurement which resulted in embarrassing social encounters. The cases of the two brothers are presented.

Results: The older brother aged 15 and the younger brother aged 14 years. Both had abnormal bilateral and symmetric growth of the jaw resulting in a wide jaw appearance and a round and swollen appearance of cheeks. They also had no teeth on the lower jaw and loose or misplaced teeth on the upper jaw. The parents and a third brother were unaffected. Both children didn't have mental retardation. The older brother had more severe disfigurement, and many people were asking him to remove the mask he is wearing. He also had very poor vision of left eye resulting from the pressure effect and upward displacement of the eye. The younger brother had a surgical operation to remove a benign tumor from the lower jaw which reduced his disfigurement.

Conclusion: Awareness of doctors with this condition "Cherubism" is helpful, and denosumab can be tried in severe cases based on the evidence provided by Bar Droma et al (2020).

Keywords: cherubism; rare disease; awareness; evidence-based treatment

\section{Introduction}

Cherubism is a very rare, mostly a childhood condition that can be horribly disfiguring. The patients are born normal at birth, but experience rapid painless, non-neoplastic growth of their jaw mostly during the period from 2 to 8 years. The abnormal bilateral and symmetric growth of the jaw commonly results in a wide jaw appearance and a round and swollen appearance of cheeks. Patients also have loose, misplaced, or missing teeth, and their eyes that turn upward in advanced stages. After the age of eight years, the progression of the condition commonly stops or increase slowly until puberty. The abnormal growth of the jaw is resulting from auto-inflammation of bones causing proliferative fibroosseous mandibular and maxillary masses. Most cases of cherubism are hereditary, and have variable severity ranging from very mild or no symptoms to a horribly disfiguring condition with pressure effects jeopardizing vision [1-13].
There are a tremendous number of rare genetic conditions syndromes, and it is difficult for most doctors to develop adequate knowledge that help them in making an early useful diagnosis for many of these conditions they may encounter [15-8].We have previously reported our extensive experiences with the diagnosis of rare genetics disorders in a plethora of publications. We have previously reported a large number of rare conditions in Iraq [19-27], and we have also helped physicians in the diagnosis and publication of rare syndromes observed in other countries [28]. The aim of this papers is to help physicians in advancing the diagnostic skills in the field of clinical genetics by reviewing briefly a rare syndrome that have not been reported in Iraq, but it is associated with certain clinical characteristics that allow an early diagnosis when seen for the first time.

\section{Patients and methods}


During the last week of January, 2021, several TV channels presented and discussed the problem of two brothers from Egypt who were considered to have a very rare poorly defined condition that has been associated with progressive disfigurement which resulted in embarrassing social encounters. The cases of the two brothers are presented.

\section{Results}

The older brother aged 15 and the younger brother aged 14 years. Both had abnormal bilateral and symmetric growth of the jaw resulting in a wide jaw appearance and a round and swollen appearance of cheeks. They also had no teeth on the lower jaw and loose or misplaced teeth on the upper jaw. The parents and a third brother were unaffected. Both children didn't have mental retardation.

The older brother had more severe disfigurement, and many people were asking him to remove the mask he is wearing (Figure-1). He also had very poor vision of left eye resulting from the pressure effect and upward displacement of the eye. The younger brother had a surgical operation to remove a benign tumor from the lower jaw which reduced his disfigurement (Figure-2).
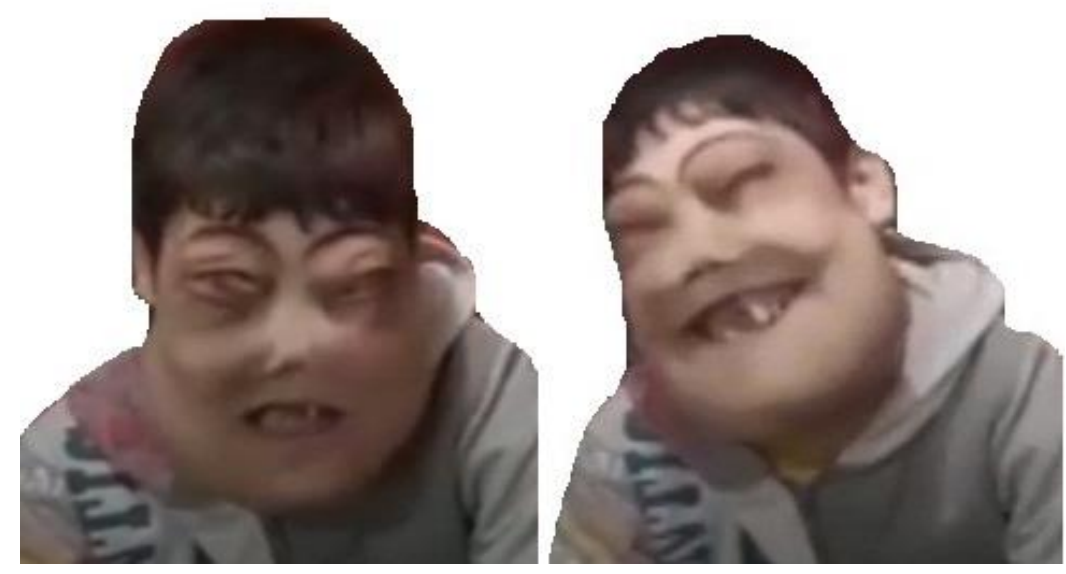

Figure 1: A sketch of the older brother was frequently being asked by people who do not know him to remove the mask he is wearing

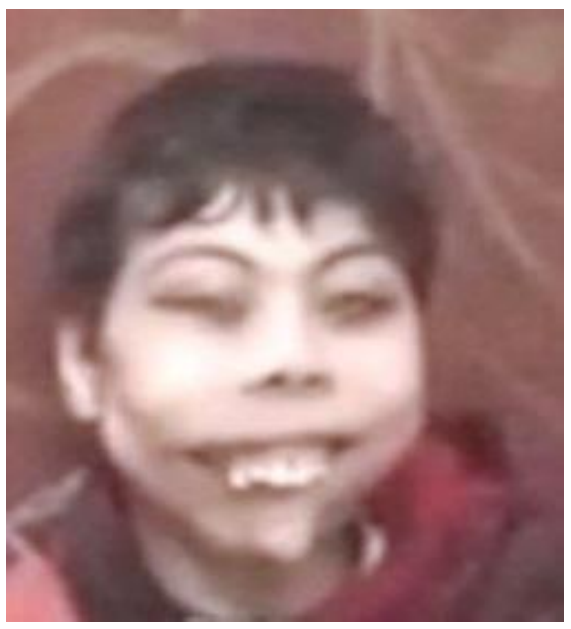

Figure 2: A sketch of the younger brother who had a surgical operation to remove a benign tumor from the lower jaw which reduced his disfigurement

\section{Discussion}

Cherubism was first reported in 1933 by Jones, who named the condition "Familial multilocular disease of the jaws" [29]. Thereafter, the cystic nature of the condition was denied. In a later publication Jones [1], and called the condition "cherubism." Cherub means the angels depicted in baroque arts with a childish, full-cheeked faces and gazing upward.

Most cases of cherubism are hereditary, and most of the reported cases were considered to have an autosomal dominant. Bixler and Garner (1971) reported a family with autosomal dominant cherubism including two brothers in a sibship of five who have each had two affected sons show none of typical clinical features of the disease. Their parents also appear unaffected [10]. Peters (1979) reported one family with twenty patients having autosomal dominance pattern of inheritance with a penetrance of 80 percent [11].

However, Kozakiewicz and colleagues (2001) reported five patients whom considered most likely to have an autosomal recessive inheritance rather than autosomal dominant inheritance [12]. In 2003, Ongole and colleagues reported the occurrence of cherubism in siblings, and counted about 200 cases previously published in the medical literature [13]. 
In addition, the occurrence of non-hereditary cherubism has been reported as early as $1960[5]$.

Treatment options for cherubism include conservative management in this condition, surgical interventions [9, 11] Fleuchaus and Buhner (1967) described the treatment of cherubism by curettage and autogenous bone chips [9], and Peters (1979) recommended avoiding treatment with radiotherapy [11].

Bradley et al (2020) reported that treatment of a 13-year-old boy who had severe cherubism with oral alendronic acid which was used after surgical debulking was not of obvious benefit [30].

Bar Droma et al (2020) reported that treatment of two patients with denosumab which can have a beneficial effect on the associated giant cell granuloma resulted in a positive outcome [31].

\section{Conclusion}

Awareness of doctors with this condition is helpful, and denosumab can be tried in severe cases based on the evidence provided by Bar Droma et al (2020).

\section{References}

1. Jones WA, Gerrie J, Pritchard J. (1952) Cherubism: a familial fibrous dysplasia of the jaws. Oral Surg Oral Med Oral Pathol. 5(3):292-305. PMID: 14911174.

2. Bruce KW, Bruwer A, Kennedy RL. (1953) Familial intraosseous fibrous swellings of the jaws (cherubism). Oral Surg Oral Med Oral Pathol. 6(8):995-1014. PMID: 13087995.

3. Franklin AW. (1958) Three cases of cherubism. Proc R Soc Med. 51(4):286-8. PMID: 13554453.

4. Choremis K, Papadatos C, Caterellos C. (1959) Familial multilocular cystic disease of the jaws. Helv Paediatr Acta. 14:396-9. PMID: 13810007.

5. El-Toraei MC. (1960) A case of non-hereditary "cherubism". Vestn Khir Im I I Grek. 84:107-10. PMID: 13832468 [Article in Russian].

6. Abbey FS, Reece CH. (1961) Cherubism: report of three cases. J Oral Surg Anesth Hosp Dent Serv. 19:63-70. PMID: 13680915.

7. Foissin B, Ohanian D. (1965) A propos de deux observations de chérubisme [Apropos of 2 cases of cherubism]. Ann Otolaryngol Chir Cervicofac. 82(6):467-72. PMID: 5835312 [Article in French].

8. Hiroto I, Nomura Y, Shin T, Tomita S, Nakajima T. (1967) [Cherubism (familial fibro-osseous disease of the jaws)]. Nihon Jibiinkoka Gakkai Kaiho. 70(7):1237-42. PMID: 5183704 [Article in Japanese].

9. Fleuchaus PT, Buhner WA. (1967) Cherubism treated by curettage and autogenous bone chips: report of case. J Oral Surg. 25(4):348-55. PMID: 5337897.

10. Bixler D, Garner LD. (1971) Cherubism: a family study to delineate gene action on mandibular growth and development. Birth Defects Orig Artic Ser. 7(7):222-5. PMID: 5173208.

11. Peters WJ. (1979) Cherubism: a study of twenty cases from one family. Oral Surg Oral Med Oral Pathol. 47(4):307-11. Doi: 10.1016/0030-4220(79)90251-2. PMID: 285398.

12. Kozakiewicz M, Perczynska-Partyka W, Kobos J. (2001) Cherubism: clinical picture and treatment. Oral Dis. 7(2):12330. PMID: 11355438.
13. Ongole R, Pillai RS, Pai KM. (2003) Cherubism in siblings: a case report. J Can Dent Assoc. 69(3):150-4. PMID: 12622878.

14. Al-Mosawi AJ. (2016) Mostyn Embrey syndrome. $1^{\text {st }}$ ed., Saarbrücken; LAP Lambert Academic Publishing.

15. Al-Mosawi AJ. (2016) Congenital Chevalier Jackson syndrome. $1^{\text {st }}$ ed., Saarbrücken; LAP Lambert Academic Publishing.

16. Al-Mosawi AJ. (2017) Unilateral Renal Agenesis and the Awareness of Mostyn Embrey Syndrome. Journal of Renal Medicine. 1(1):1-4.

17. Al-Mosawi AJ. (2019) The Twenty Eighth Case of Congenital Chevalier Jackson. Annals of Clinical Case Reports. 4: 1-4.

18. Al-Mosawi AJ. (2019) The Case Number 104 of Sanjad Sakati Richardson Kirk Syndrome. Journal of Research Notes.2 (2): 13. Article 1014.

19. Al-Mosawi AJ. (2011) Rare genetic disorders in Iraq. $1^{\text {st }}$ ed., Saarbrücken; LAP Lambert Academic Publishing: (ISBN: 9783-8473-1702-9).

20. Al-Mosawi AJ. (2019) Genetic and Hereditary Disorders in Iraqi Children. Ann Med \& Surg Case Rep. 1 (2): 1-8 [AMSCR1000011].

21. Al-Mosawi AJ. (2020) Clinical Genetics and Dysmorphology: Our Extraordinary Experiences. SunKrist Journal of Neonatology and Pediatrics. 2 (1): 1-10.

22. Al-Mosawi AJ. (2020) Uncommon and Rare Pediatric Syndromes Associated with Surgical Conditions in Iraqi Children. Global Journal of Surgery and Surgical Techniques. 2 1: 1-8.

23. Al-Mosawi AJ. (2018) The Uncommon and Rare Genetic Disorders in Iraq. $1^{\text {st }}$ ed., Saarbrücken; LAP Lambert Academic Publishing.

24. Al-Mosawi AJ. (2020) Les maladies génétiques rares et peu communes en Irak (French edition). Editions Notre Savoir.

25. Al-Mosawi AJ. (2020) Clinical genetics and dysmorphology: A unique pioneering experiences $.1^{\text {st }}$ ed., Saarbrücken; LAP Lambert Academic Publishing.

26. Al-Mosawi AJ. (2020) Klinische Genetik und Dysmorphologie: Eine einzigartige bahnbrechende Erfahrung (German Edition). Verlag Unser Wissen.

27. Al-Mosawi AJ. (2020) Genetica clinica e dismorfologia: Un'esperienza pionieristica unica (Italian Edition). Edizioni Sapienzax.

28. Al-Mosawi AJ, Fewin L. (2009) The first case of NiikawaKuroki syndrome in Kazakhstan associated with café au lait spots. G Ital Dermatol Venereol. 144(5):613-5. PMID: 19834439.

29. Jones WA. (1933) Familial multilocular cystic disease of the jaws. Am J Cancer. 17 (4): 946-50.

30. Bradley D, Patel V, Honeyman C, McGurk M. (2020) Adjuvant Alendronic Acid in the Management of Severe Cherubism: A Case Report and Literature Review. J Oral Maxillofac Surg. S0278-2391(20)31213-1. PMID: 33159843.

31. Bar Droma E, Beck-Rosen G, Ilgiyaev A, Fruchtman Y, Abramovitch-Dahan C, Levaot N, Givol N. (2020) Positive Outcomes of Denosumab Treatment in 2 Patients With Cherubism. J Oral Maxillofac Surg. 78(12):2226-2234. 